\title{
2. Insights from Walter Bagehot
}

\section{Perry Mehrling ${ }^{1}$}

My first book, The Money Interest and the Public Interest: American Monetary Thought, 1920-1970 (1997) is a history of monetary economics. My second book, Fischer Black and the Revolutionary Idea of Finance (2005) is a history of financial economics. Those two topics come together in my talk today on insights from history for today's trying economic times - and in my third book, The New Lombard Street: How the Fed Became the Dealer of Last Resort (2011). The connection between the two topics is what the recent crisis has been all about - the interaction of the capital markets and the money markets, how they got intertwined, and how that came unglued in the crisis. And we are still gluing it back together.

I have been teaching money and banking at Barnard College at Columbia University for 15 years and a lot of my students actually work in the money markets, or down at Goldman Sachs, or somewhere like that. When I first started teaching it, I found that there was a big disconnect between the lives the students were experiencing and what was in the textbooks. So eventually I got rid of the 
textbooks. I started teaching The Money Market by Marcia Stigum (1989), which is a desk reference for people who trade in the repo market and other money markets. I used to tell them, 'Think of this as the sacred text of a foreign tribe of some kind and we're anthropologists trying to learn how these people think, how they organize their culture and so forth; we're trying to understand them.' It is quite some sacred text, a big thick book, now in its fourth edition. ${ }^{2}$

There are also daily texts of the tribe, most notably The Financial Times. Everything that I really know about the money markets comes from those two things, reading The Financial Times every day, and reading Marcia Stigum several times. The first time I read Stigum, I could not make head nor tail of it. But eventually I learned it, so when the crisis hit I actually knew stuff about the world. I had been toiling away writing these history of thought books, but now everyone wanted insights from history. Princeton University Press asked me to write a book that puts the crisis into perspective.

The original book Lombard Street was published in 1873 by the English economist, Walter Bagehot - pronounced Badge-it. The copy I own is inscribed: 'Merry Christmas, to father from Ed, 1907'; 1907 of course being the year of financial crisis that finally woke up Americans to the need for a central bank, and one of the models they looked to was the Bank of England. It is a lovely book written in beautiful English. Walter Bagehot, who was born in 1826, was a true polymath. After 
earning a law degree and working in his father's business, he became a journalist and writer, serving as editor-in-chief of The Economist magazine - which had been founded by his fatherin-law. In Lombard Street, after talking to a lot of bankers and looking at history, Bagehot concluded that there were certain principles that had evolved in England. He distilled all that and identified what to do in times of crisis. In times of crisis, the central bank should lend freely at a high interest rate on good security, or on security that would be good in normal times. That is the famous Bagehot principle for what to do in a financial crisis. There is nothing in the book about monetary policy, about stabilization of business cycles or anything like that. It is all about financial crises, and how a central bank - even a private central bank, as the Bank of England was at that time - has this responsibility and ability to intervene as 'lender of last resort' in times of crisis.

In my opinion, this is the beginning of monetary science and the great British central banking tradition grew from this. There were precursors, such as Henry Thornton, but Bagehot's book was a crystallizing moment, since once central banks took responsibility for crises, they began to ask 'Wouldn't it be better if we just avoided these crises in the first place?' They began to use monetary policy to try to stabilize things and prudential policy to make sure banks had spare capital, or liquidity reserves. All of these policies came after and built on Bagehot's insights. 
I think we are at a moment today like 1873, where we have built an enormous intellectual apparatus on the top of this book. But Bagehot's book is about a financial system, a monetary system that bears very little resemblance to the modern one. There is a lot of resemblance in a certain way, institutionally. But the capital market, the globalization of securities markets, securitization, derivatives markets, all this is not in Bagehot's book. Life was a little simpler back in 1873. They did not have computers, automated trading, the ability to electronically send money around, flash crashes, and all this stuff.

I am inspired by Bagehot because he looks at history to try to distill wisdom from the pragmatic, practical experience of practical bankers. He looks at institutions and asks, 'How do these markets actually work?' He is concrete, he looks at laws and wrote a treatise on constitutional law - The English Constitution (1867). He thought about social welfare - what can we do to make things better? This was before the professionalization of economics. He came from the practical bankers' literature, written by actual bankers, not economists. He did not say, as economists usually do, 'let me reason through this on first principles; write down a utility function'. There is nothing like that in this book, which is why it is a little hard sometimes for modern readers.

I titled my own book The New Lombard Street. The people at Princeton University Press wanted to know what that means - is not Lombard Street 
that twisty street in San Francisco? To clarify what I meant I added the subtitle, How the Fed Became the Dealer of Last Resort - 'dealer of last resort' as opposed to 'lender of last resort'. The book is somewhat of a capsule history of the Fed from its foundation in 1913, from the point of view of a historian of thought more than an economic historian or even a bank historian. I argue that we are at a 'Bagehot moment' in history where we have been building a global capital market, a market-based banking system, without really knowing what we are doing or thinking through what we are doing and imagining that all the rules of the old system will still apply. Certainly some of the basic principles still apply, but my argument is that they need to be rethought from the ground up. In the same way that Bagehot did, we need to start from a different place. We need to start from dealer of last resort and build then on top of that a new understanding of what monetary policy can do, of what prudential policy would be.

Recall that Bagehot said the lender of last resort was to (1) lend freely (2) at a high rate (3) against good security. Here are three new principles for a dealer of last resort in a world of market-based credit, which has replaced the lender of last resort operating in a world of bank-based credit. $^{3}$ The dealer of last resort (currently the Federal Reserve System) needs to focus on (1) asset markets, not just banking institutions, (2) the outside spread, not the inside spread, and (3) the core, not the periphery. 
Today we are supporting 'asset markets, not just banking institutions'. Dealers make markets. They are willing to buy when no one else wants to buy, and they absorb it into their inventory. They are willing to sell when no one else is willing to sell, and they go short. They are the reason there is liquidity in markets. When dealers fail to do this because they do not have any money or they are broke, the central bank does this. And that is exactly what the central bank actually did in this crisis.

'Outside spread, not inside spread' means when the dealer of last resort is buying an asset it does not buy it at its fair value; it buys well below the fair value. When it sells it does not sell it at the fair value. If you are selling to the Fed in a time of crisis you are selling to them pretty cheap. Just as when you are borrowing from the Fed, in its lender of last resort role, you are borrowing at a pretty high price.

'Core, not periphery' means that the Fed is not to support all markets equally. There is a hierarchal structure of markets. They need to choose particular core markets to support and allow arbitrage relationships to influence prices in other related markets. Typically the Fed has operated in Treasury markets, but that turned out not to be enough in this crisis, so the Fed went into mortgage-backed securities markets.

The dealer of last resort is what I am proposing as the appropriate starting place in thinking about the role of a central bank in a crisis time for 

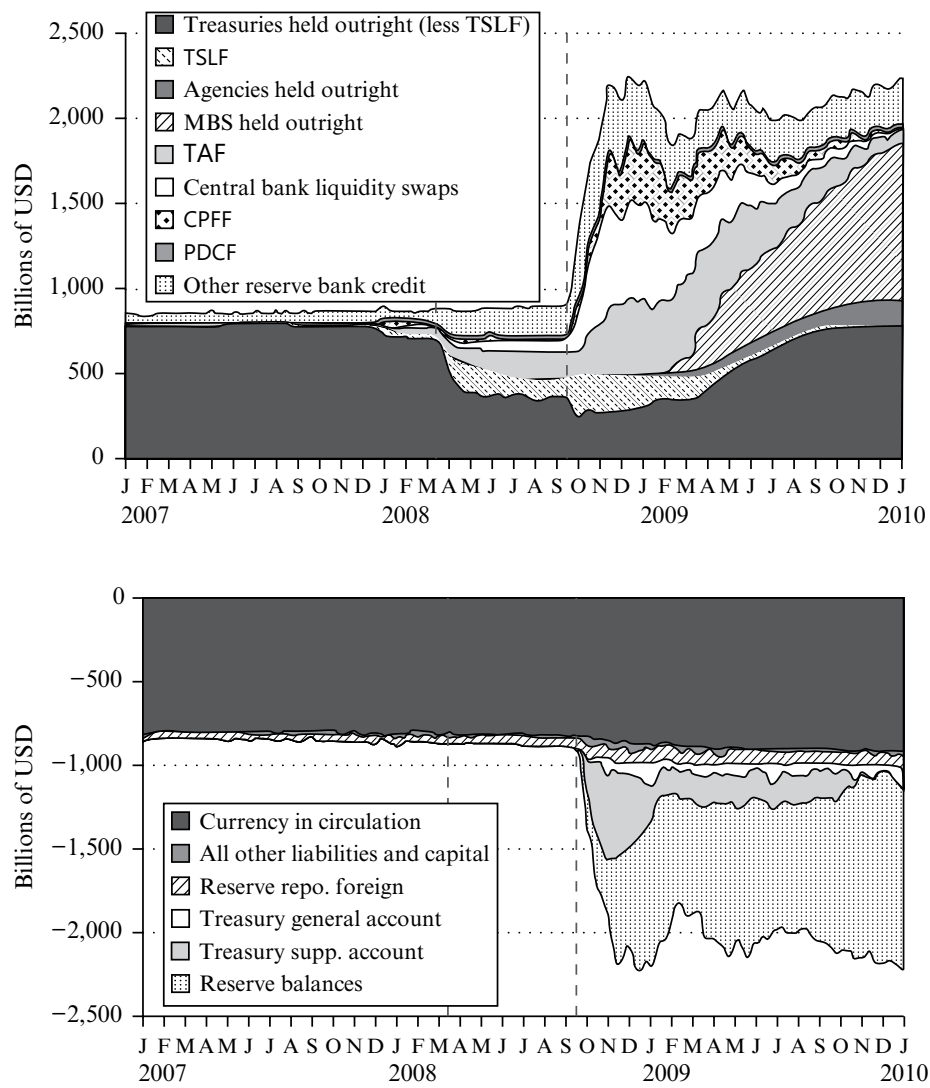

Figure 2.1 Transformation of the Fed

a market-based credit system, as opposed to the lender of last resort, which is appropriate for a bank-based credit system.

The balance sheet of the Fed for the last few years is shown in Figure 2.1. The two vertical lines are when Bear Stearns collapsed and when Lehman Brothers and AIG collapsed. The balance sheet shows what the Fed did during this 
crisis - up until Bear Stearns the balance sheet does not change very much. The Fed moved the interest rate from 5 percent down to 2 percent, but you cannot see that on the balance sheet. After Bear Stearns was what I call the lender-of-lastresort period, when the Fed was selling off its Treasury bills and lending the proceeds to banks. The size of the balance sheet stayed the same, but the composition changed. After Lehman and AIG collapsed all hell broke loose, and the Fed began substituting for a collapsing money market. Banks that did not trust each other were making deposits at the Fed, which took that money and lent it out. The Fed's balance sheet tripled in the space of a few weeks, and it was not just a domestic thing. It was an international thing. There are hundreds of billions of dollars of liquidity swaps, loans to foreign central banks, visible in the balance sheet.

When the money market fell down, the Fed began purchasing trillions of dollars' worth of mortgage-backed securities. As the money markets came back into line these facilities began liquidating. But instead of allowing the balance sheet to shrink the Fed went into the capital markets and bought mortgage-backed securities, about a trillion dollars' worth. The world has changed. There is a lot of talk about exit strategies. I think we are in a brave new world.

Figure 2.2 gives the Federal Reserve's balance sheet (in trillions of dollars) for July 4, 2007 - before the crisis - and December 15, 2011. Initially, the Fed's balance sheet was almost all Treasury bills 
December 15, 2011

\begin{tabular}{|lr|lr|lr|ll|}
\hline \multicolumn{2}{|l|}{ Assets } & \multicolumn{2}{|l|}{ Liabilities } & & Assets & & \multicolumn{2}{l|}{ Liabilities } \\
\hline Treasuries & $\$ 0.79$ & Currency & $\$ 0.82$ & Treasuries & $\$ 1.7$ & Currency & $\$ 1.0$ \\
& & Reserves & 0.01 & MBS/GSE & 0.9 & Reserves & 1.6 \\
Other & 0.12 & Other & 0.08 & Other & 0.3 & Other & 0.3 \\
TOTAL & 0.91 & TOTAL & 0.91 & TOTAL & 2.9 & TOTAL & 2.9 \\
\hline
\end{tabular}

Figure 2.2 Fed balance sheet transformed (\$ trillions)

on one side, and almost all currency on the other side - with just a tiny little bit of reserves and things needed for the banking system. In just four years the balance sheet tripled in size, with a massive change in composition. There are $\$ 1.6$ trillion worth of excess reserves and almost a trillion dollars' worth of mortgage-backed securities and other similar things (MBS/GSE), which were never on the balance sheet before. In addition, operation twist means that the composition of the Treasuries changed.

These changes are the consequence of a larger longer-term transformation from a bank-based credit system to a market-based credit system. The Fed rescued the market-based credit system. When I say bank-based credit system, I mean the traditional bank, a Jimmy Stewart bank from the movie It's a Wonderful Life. A traditional bank takes deposits from the community and lends them out to homeowners and others in the community. It is backstopped by federal agencies; there is a liquidity backstop by the Federal Reserve Bank, so that if it ever runs out of reserves it can discount assets 
CDO

Shadow Bank

MMMF

\begin{tabular}{|l|l|l|l|l|l|}
\hline Assets & Liabilities & Assets & Liabilities & Assets & Liabilities \\
\hline RMBS & $\begin{array}{l}\text { Hi tranche } \\
\text { Mid tranche } \\
\text { Lo tranche }\end{array}$ & $\begin{array}{l}\text { Hi tranche } \\
\text { Liquidity put }\end{array}$ & RP & $\begin{array}{l}\text { RP } \\
\text { Liquidity put }\end{array}$ & 'Deposits' \\
\hline
\end{tabular}

Traditional Bank

FRB backstop

\begin{tabular}{|c|c|c|}
\hline Sols & Assets & Liabilities \\
\hline$\rightarrow$ & $\begin{array}{l}\text { Loans } \\
\text { Reserves }\end{array}$ & $\begin{array}{l}\text { Deposits } \\
\text { Capital } \\
\text { Liquidity put }\end{array}$ \\
\hline
\end{tabular}

FDIC backstop

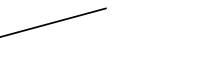

Figure 2.3 From bank-based credit to market-based credit

of some kind at the Fed and get more reserves. It will not run into liquidity troubles. And there is the Federal Deposit Insurance Corporation (FDIC) backstop to protect these deposits. If it ever runs out of capital because its loans go bad, widows and orphans do not suffer from losses because the government insures their deposits. That is the traditional banking system and it very much shapes the way we think about what banking is.

But today we have a shadow banking system and market-based credit, which we can understand by looking at the top of Figure 2.3. Begin with residential mortgage-backed securities (RMBS). These are securitized loans. But underneath they are backed by mortgages, loans to households. Way over on the other side of the figure there are deposits. One way to understand the shadow banking system is that it is exactly the same as the traditional system except without the government backstops, and with a lot of people in between collecting fees. 
The mortgage-backed securities are sliced and diced into tranches. The high tranche, which is rated AAA, can be used as security to borrow in the repo market or the asset-backed commercial paper market. The borrowing is from a money market mutual fund (MMMF), let us say, that is issuing deposits against that to institutional investors. I am simplifying somewhat but this gets at the essence of the situation.

Regulators encouraged the development of the shadow banking system. They were interested in protecting the deposits and interested in the safety and soundness of the banking system. The shadow banking system seemed to be taking the risk out of the traditional banking system and moving it to firms like Goldman Sachs. They know what they are doing; they are professionals. If they lose money, who cares? They can handle it, so it was not thought that we needed to pay attention to them. But not enough people noticed that there was never a separate shadow banking system. It was always intertwined with the existing banking system. Ultimately, the traditional banking system became the lender of last resort for the market-based credit system. So when these firms ran into liquidity trouble they went to their parents - to Citibank, to UBS - and asked for help. And their parents helped. As a consequence, all of this trouble landed on the balance sheet of the traditional banking system, and then it did not go away. As a consequence, when they ran into trouble it landed on the balance sheet of the 
Fed, as we just saw. That is how the crisis played out, given the hybrid character and interactions between these systems.

It was a new kind of crisis that required a new kind of solution. It was not enough just to lower the interest rate to 2 percent, and ultimately to 0 percent. That did basically nothing. The balance sheet expansion was necessary. That is what I call the dealer of last resort.

Many observers believe that the traditional banking system - real banking - is good but shadow banking is bad; concluding that regulation should basically eliminate the shadow banking system. That approach seems unhelpful to me. I think shadow banking is here to stay. How would we manage a system if it were only shadow banking?

There are two key institutions that we need to distinguish. One is global banks, which collect money from all over the world, and then lend money all over the world. They are basically market makers in money and they are in the funding business. Many of the European banks that are in trouble right now are basically in this business, such as UBS. Citibank was in this business too. But there is another separate piece with different laws of motion - the risk-transfer business. The center of this market is derivative dealers, who offer a buy/sell spread for risk. They will sell you risk exposure if you want it and they will buy it from you if you do not want it. The credit default swap (CDS), which deals with 
default risk, is an example, as is the interest rate swap (IRS) - that is the risk that short-term interest rates will move relative to long-term interest rates. There are other kinds of risks, too. But CDSs and IRSs are where most of the action and almost all the volume is.

These are today's key market makers - the market makers in risk and market makers in funding - that are at the core of the entire market-based credit system. So backstopping the activities of these players is what central banking of the future is going to be about.

The central bank balance sheet has an implicit, maybe explicit, liquidity put as the backstop for both global bankers and derivative dealers. The Fed is not allowed to trade in credit default swaps and interest rate swaps directly, but there are equivalents to this. An interest rate swap is really just the same as a long position in a long-term bond and a short position in a short-term bond. A credit default swap, similarly, is just a long position in a risky security and a short position in a safe security. So think of the Fed as having these risk exposures, and as a consequence of the crisis taking these risk exposures onto its own balance sheet as a backstop.

Unless you have a sense of the system as a whole, it does no good to think about individual bricks. ${ }^{4}$ So, now let us go back and fill in.

I said that all of monetary policy, all of monetary theory, is built on Bagehot. It is an exaggeration. But we honor him, because once the central bank 
took on this responsibility it realized it would be a good thing if we could just prevent crises from happening in the first place. This means that there are big challenges ahead for the Federal Reserve.

The central bank must think about prudential policy, solvency, but in the market-based credit system it is going to be not concerned about keeping banks from failing, but about keeping certain instruments from failing in some sense. The Fed's stabilization policy has turned into sort of inflation fine tuning or inflation targeting, but all the action is what is happening on the balance sheet. There are a lot of technical changes in moving from a bank-based credit system to a market-based credit system. We basically have to redo everything from scratch. A lot of the old pieces will be still okay, but we have to look at each little piece and build up the system. We can solve this eventually, as long as we ask the right questions. I do not know that we are asking the right questions right now.

The biggest challenge is the political economy challenge - actually three political economy challenges - because in the United States the role of the central bank has always been highly political, highly charged, and it is even now in this election, as some people want to end the Fed. The first political economy challenge has to do with the relationship between the Fed and the federal government. There is much anxiety about fiscal dominance - the Treasury dominating the Fed. This is not that important for the Fed right now, 
but it is playing out in Europe - the notion that the European Central Bank (ECB) is in some sense monetizing government debt indirectly through its trillion euro long-term refinancing operations (LTROs). The second political economy challenge is what is the relationship between the Fed and Wall Street? Is the Fed the tool of Goldman Sachs or is it the master of Goldman Sachs? The Fed is supposed to be a democratic institution of some kind, but on the other hand, it is actually the bank for bankers. That hybridity is a problem. The third political economy arises because of globalization. When we created the Fed we never intended it to be the central bank for the world. In 1913 when the Fed was created the pound was dominant, and the Bank of England was the central bank for the world. A lot has happened since then, and we have not gotten used to it. But the Fed has to be concerned about global stability; we cannot ignore this issue as we have been.

At the birth of the Fed in 1913 there were a number of issues on the table. We got the Fed as a reaction to the crisis of 1907 in which J.P. Morgan acted as the lender of last resort for his friends on Wall Street. That was seen as somehow unacceptable. The second memory was the Civil War and the greenback era when the government got control of the banking system and used it to finance the war. There is a great history in America of worrying that if the government ever got a central bank it would use it to finance its projects. Big finance and big government are the boogie men 
in American monetary history, and the Federal Reserve is actually both of these together. It is the boogie man squared.

The traditional national banking practice which involved using bonds and sort of primitive repo-type instruments to transfer between banks - was also there in 1913. This was sort of shadow banking. So shadow banking is actually old in America. But it was considered to be the source of all the crises, so we tried to get rid of it by creating the Fed. The Real Bills Doctrine, which we borrowed from Britain, imagined that banking would be a lot better if we forced banks to focus their lending on short-term self-liquidating bills of some kind - these were bills issued by manufacturers and farmers, not necessarily just traders, on goods on their way toward sale. These were real bills, as opposed to finance bills (which were basically anything with a Wall Street name on it) or government bills (anything from Washington). The legislation that established the Fed deliberately aimed to keep finance and government out of banking - let us make central banking be about lending to the farmers and manufacturers in the hinterland. That is how we got a central bank. We got a central bank by hiding from the fact that our system is not actually built around credit like this.

These silos and silences about the nature of the system were built in at the beginning in 1913. And it only got worse. The Fed turned to government finance almost immediately because of World War I, so in fact, the central bank wound up being 
built around government finance right away. We got used to that, because it was for a good purpose - we had to defeat the enemy.

After World War I, Benjamin Strong, Governor of the New York Fed, invented open market operations, which involved trading with the dreaded Wall Street. He was in the bond market, buying and selling bonds, lending money to dealers. He had to justify this in some complicated way. The Tenth Report of the Fed is a fantastic work of literature in this regard, dancing around all of these difficult issues. Then came a wonderful piece by Fed Chair William McChesney Martin's committee in 1952, which said after World War II it is all going to be Treasury bills; we are going to make sure there is a liquid market in Treasury bills. We will backstop that. That will be the centerpiece of the entire financial system. ${ }^{5}$

The public got used to the Fed's role in government finance but we did not yet need to deal with its roles in capital finance and international finance. We did not have to deal with capital finance after World War II, partly because capital markets were destroyed and it took them a while to get back into business. We did not have to really deal with the international role of the dollar because there were a lot of constraints on capital flows under the Bretton Woods system and the IMF.

So we just kept ticking along. All the textbooks focus on the federal funds rate target and maybe its effect on the term structure of interest rates, 


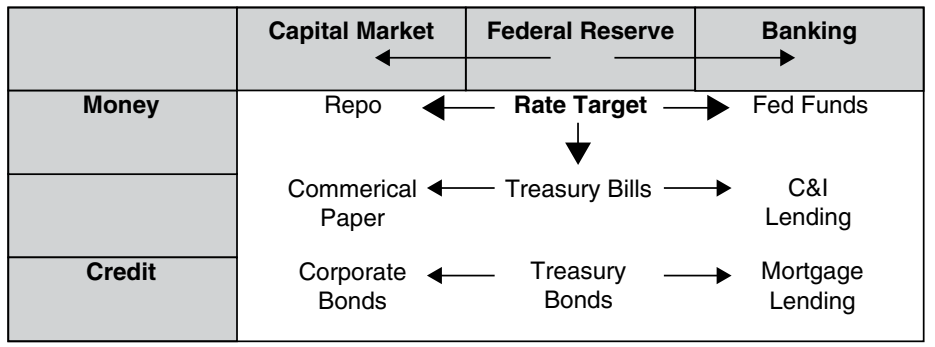

Figure 2.4 The language of money, capital finance

assuming that the private sector through some mechanism of its own transfers the Fed's target rate into a short-term rate and a long-term rate, as shown in Figure 2.4.

Similarly, for the international dollar, textbooks focus on the domestic dollar and all the credit downstream from it. There is this international dollar that people use to borrow and lend abroad, but that is no problem for us. It has an exchange rate with other currencies, but that is no problem for us. The textbooks just focus on the domestic dollar, so the international dollar is 'out of sight, out of mind' in discussions of monetary policy.

This narrow focus worked for a while until it did not, because, of course, big finance came back and globalization brought back the rise of the big wide world as a third boogie man. Americans have always been somewhat xenophobic, so the notion that the Fed would do anything to stabilize the rest of the world was unacceptable. Fed Chairman Paul Volcker had his own Benjamin Strong moment in 1979 when he had to find some 


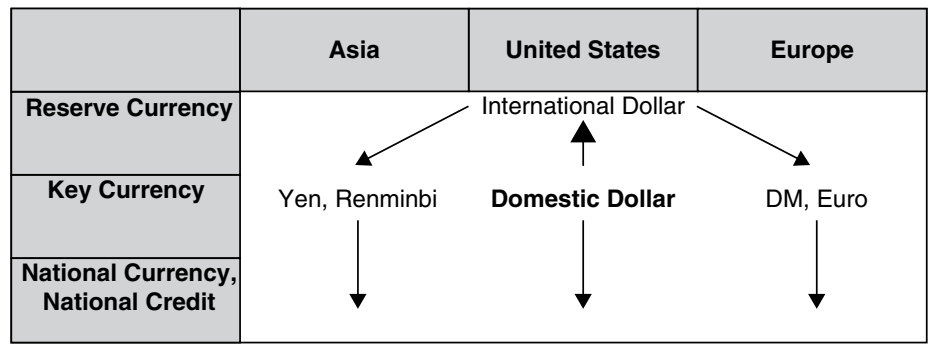

Figure 2.5 The language of money, international dollar

reason for saving the dollar as the world reserve currency. Why would we save the dollar as the world reserve currency? He had to create some other reason for doing this, so he had a conversion to monetarism for convenience. But he knew what he was doing and everyone in the know knew what he was doing. Maybe it was the right thing to do, but economists could not talk about it. You could not talk about it on the news, and that has had bad consequences, because we as a people have a very low understanding of how the system works and what it requires to be successful.

Here is an example. When Fed Chairman Ben Bernanke was called before Congress recently, Representative Grayson pointed to the $\$ 600$ billion of liquidity swaps on the Fed's balance sheet and asked Bernanke to explain what that is. "These are loans to foreign central banks, aren't they?' Ben Bernanke said, no, that is not right, they are not loans; this is an old instrument we have used forever. But this was all mumbo-jumbo. They are loans to foreign central banks. Bernanke, a 
former professor from Princeton, missed a teachable moment. Instead, he punted. Maybe he had to punt because of political pressure, but this is just an example of what I mean. By not having this knowledge we wind up not being able to speak the truth. So we are not able to say that what the Fed did in handling the crisis of the shadow banking system is ultimately about dealing with a crisis of the capital finance system and the international role of the dollar. The shadow banking system is an international system, funded internationally. The international role of the dollar and the role of the Fed supporting capital markets are deeply implicated in the crisis of this market-based credit system.

In wartime the Fed backstops the market for Treasury bills, allowing the government to issue as many Treasury bills as it needs to defeat the enemy. If the private sector will buy them, that is fine. If not, the Fed buys them. The recent crisis required the Fed to backstop the entire world - it had to become the dealer of the last resort and an international lender of last resort.

Now let us return to the many faces of shadow banking. The piece of 'modern art' in Figure 2.6 is from Zoltan Pozsar, who made it when he worked at the New York Fed. You can get it online and I have a copy hanging on the wall in my office. This is a large version of the little three-part market-based credit system schematic I showed earlier in Figure 2.3. The borrowers are on the left side. There are all the people in the 


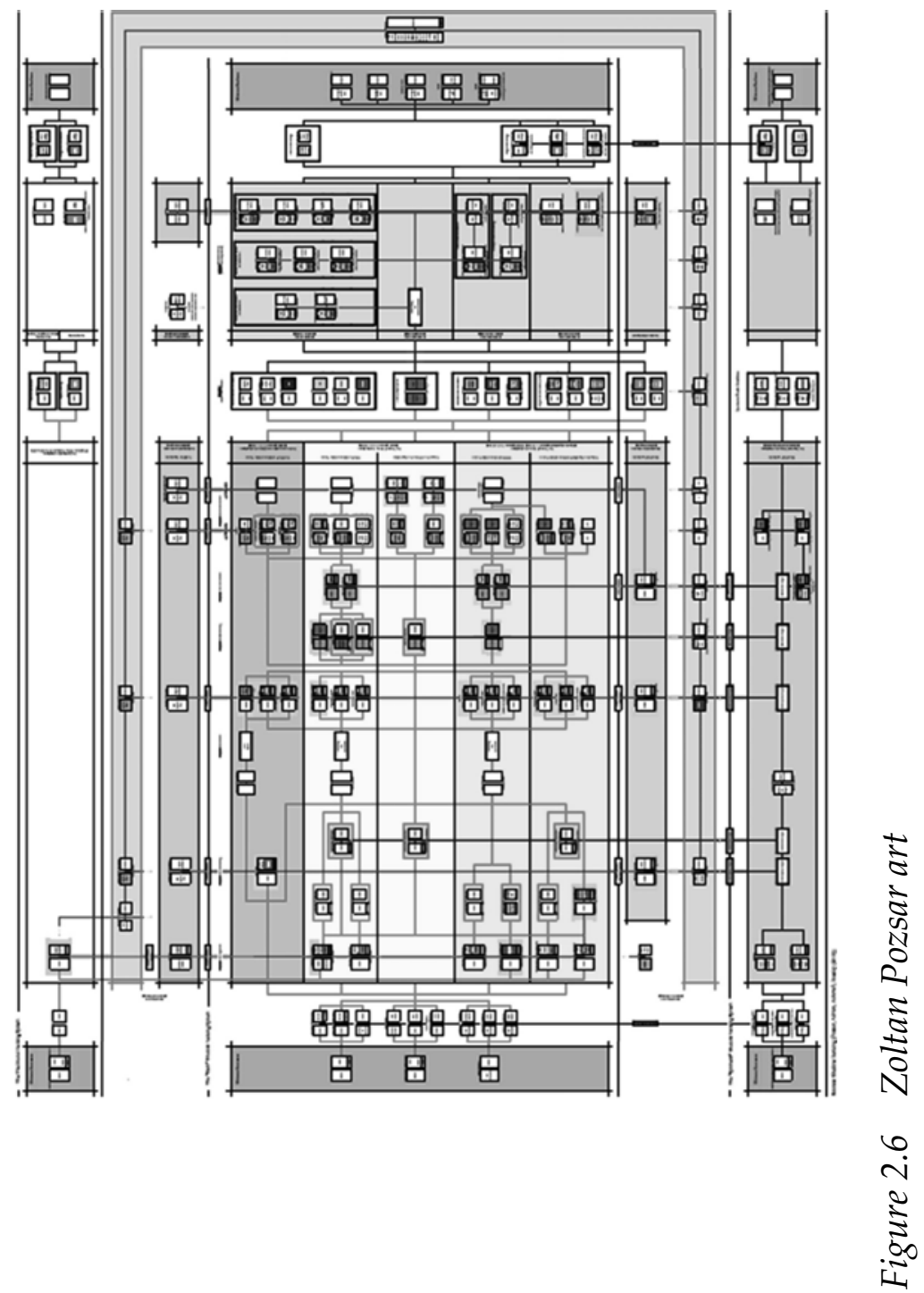


middle tranching and everything. On the right side are the people depositing money into money market mutual funds. There are so many different layers here. And wrapped around everything is the Fed, whose emergency programs essentially substituted for all of the systems identified in this diagram. This is what the New York Fed was doing during the crisis. They understood this is the system that is falling apart. So as each little chunk fell apart they created a program designed for that piece. Then another little piece fell apart and they created another fix somewhere else. The Fed was using this chart.

But you cannot understand anything about monetary theory using this chart, so I will start where I started before, with the traditional bank. The first face of shadow banking is that it is just banking. Economist Gary Gorton says this, for example. It is market-based credit, so it is subject to the same problems of banking runs, and problems like that. That view is not incorrect, but it is not everything.

There is a second face of shadow banking - the global dimension. Before this shadow banking system developed there was a global money market in which banks were taking dollar deposits and lending them in a worldwide wholesale money market. People are borrowing and lending dollars, even if their domestic currency is not dollars. Korea, for example, funded some of its development by borrowing in these global markets, and that exposed Korea to foreign 
Korean Bank

Global Bank

Dollar Bank

\begin{tabular}{|l|l|l|l|l|l|}
\hline Assets & Liabilities & Assets & Liabilities & Assets & Liabilities \\
\hline $\begin{array}{l}\text { Domestic } \\
\text { currency } \\
\text { loans } \\
\begin{array}{l}\text { FX swaps } \\
\text { \$ reserves }\end{array}\end{array}$ & $\begin{array}{l}\text { Dollar } \\
\text { funding }\end{array}$ & $\begin{array}{l}\text { Dollar } \\
\text { lending }\end{array}$ & $\begin{array}{l}\text { Wholesale } \\
\text { money } \\
\text { market }\end{array}$ & $\begin{array}{l}\text { Wholesale } \\
\text { money } \\
\text { market }\end{array}$ & 'Deposits' \\
& & & & & \\
\hline
\end{tabular}

\begin{tabular}{|c|c|c|c|c|c|}
\hline \multicolumn{2}{|c|}{ CDO } & \multicolumn{2}{|c|}{ Shadow Bank } & \multicolumn{2}{|c|}{ MMMF } \\
\hline Assets & Liabilities & Assets & Liabilities & Assets & Liabilities \\
\hline RMBS & $\begin{array}{l}\text { Hi tranche } \\
\text { Mid tranche } \\
\text { Lo tranche }\end{array}$ & Hi tranche & $\mathrm{ABCP}$ & $A B C P$ & 'Deposits' \\
\hline
\end{tabular}

Figure 2.7 Shadow banking as global banking

exchange risk, because there is a domestic currency which you might hedge by holding dollar reserves, or by having a foreign exchange swap of some kind.

The crises of this system, like the East Asian Crisis of 1997, are very familiar. This apparatus, shown in Figure 2.7, is now smoothly oiled and working great. It has been through a crisis. It has been tested. Then somebody had the bright idea that we could do this very same thing, but the ultimate lending could be in dollars. The shadow banking system did that. It tapped into this global money market to finance the domestic mortgage market. It is no longer the Koreans borrowing, it is the residents of Cleveland or Arizona or somewhere else in the US borrowing in the global money markets.

But there is a third face to shadow banking - it is also a finance thing. Figure 2.8 shows 
Shadow Bank

Asset Manager

\begin{tabular}{|l|l|l|l|}
\hline Assets & Liabilities & Assets & Liabilities \\
\hline RMBS & Money & Money & Capital \\
Derivatives & & & Derivatives \\
- CDS & & & - CDS \\
- IRS & & & - IRS \\
\hline
\end{tabular}

Figure 2.8 Shadow banking as finance

a shadow bank holding residential mortgagebacked securities, funding them in this global money market by getting rid of the risk, selling it off with derivatives, credit default swaps and interest rate swaps. Imagine that the system really works perfectly, so that you could basically eliminate all your risk on one side, and it would be purchased by an asset manager on the other side. The asset manager may run a pension fund that is trying to make money for the pensioners over the long run. They are buying risky assets to get a higher expected yield, but instead of buying the assets outright, it holds all its capital in money form and gets those risks in the derivatives market. So there is a risk transfer and there is a funding transfer at the same time. This is what was happening in the shadow banking system, but not cleanly like this. This is clean. This is my model of what the future banking system looks like.

The more complete picture is shown in Figure 2.9. It requires a derivative dealer and a global money dealer in between the shadow bank and the asset manager, and that is going to be the issue. The global bank in between is the key insti- 
Shadow Bank

Global Bank

Asset Manager

\begin{tabular}{|l|l|l|l|l|l|}
\hline Assets & Liabilities & Assets & Liabilities & Assets & Liabilities \\
\hline $\begin{array}{l}\text { RMBS } \\
\text { CDS } \\
\text { IRS }\end{array}$ & MM funding & MM funding & 'Deposits' & 'Deposits' & $\begin{array}{l}\text { Capital } \\
\text { CDS } \\
\text { IRS }\end{array}$ \\
\hline
\end{tabular}

Derivative Dealer

\begin{tabular}{|l|l|}
\hline Assets & Liabilities \\
\hline $\begin{array}{l}\text { Credit Default Swaps } \\
\text { Interest Rate Swaps } \\
\text { FX Swaps }\end{array}$ & $\begin{array}{l}\text { Credit Default Swaps } \\
\text { Interest Rate Swaps } \\
\text { FX Swaps }\end{array}$ \\
\hline
\end{tabular}

Figure 2.9 Two key intermediaries

tution for the funding side. And the derivative dealer is a counterparty for the asset manager and the counterparty for the shadow bank here.

Imagine that shadow banking comes about essentially because both the theory and the institutions of modern finance have developed to enable us to do this sort of thing. Instead of buying stocks and bonds you can just hold everything in deposits and get your risk exposure with derivatives. That was not really possible in an earlier age. These are liquid markets, so it is more desirable. From this point of view the crisis seems to be the growing pains of a new system but because it was not really prepared to deal with everything we got a credit bubble. There was an attempt to take the risk out of risky assets so they could be turned into money in this very ad hoc way, through tranching, through all different kinds of things. The result was an opacity about risk exposures and mispricing. The result was a crisis, and a flight to true money. 
CDO Investment Bank

Insurance

\begin{tabular}{|l|l|l|l|l|l|}
\hline Assets & Liabilities & Assets & Liabilities & Assets & Liabilities \\
\hline RMBS & $\begin{array}{l}\text { Hi tranche } \\
\text { Mid tranche } \\
\text { Lo tranche }\end{array}$ & $\begin{array}{l}\text { Hi CDS } \\
\text { Loans }\end{array}$ & $\begin{array}{l}\text { Mid CDS } \\
\text { Lo CDS }\end{array}$ & & $\begin{array}{l}\text { Hi CDS } \\
\text { Capital }\end{array}$ \\
\hline
\end{tabular}

Shadow Bank

Pension/Insurance

Hedge Fund

\begin{tabular}{|l|l|l|l|l|l|}
\hline Assets & Liabilities & Assets & Liabilities & Assets & Liabilities \\
\hline $\begin{array}{l}\text { Hi tranche } \\
\text { Hi CDS }\end{array}$ & MM funding & $\begin{array}{l}\text { Mid tranche } \\
\text { Mid CDS }\end{array}$ & $\begin{array}{l}\text { DB/Annuity } \\
\text { Capital }\end{array}$ & $\begin{array}{l}\text { Lo tranche } \\
\text { Lo CDS }\end{array}$ & $\begin{array}{l}\text { Loans } \\
\text { Capital }\end{array}$ \\
\hline
\end{tabular}

Figure 2.10 Shadow banking as immature finance (risk transfer)

Viewing the crisis as the growing pains of a new system, we can understand shadow banking as immature finance - the risk transfer system had not grown up to be a partner with the funding system. The funding system was great, but the risk transfer system looked more like Figure 2.10. It was not clean like my third face of shadow banking. What happened, as shown in the figure, was that they tranched the mortgage-backed securities. Whoever got the high tranche got some kind of insurance on that high tranche, say from AIG. They got insurance so that they could fund the asset. Whoever took the mid tranche used the credit-default swaps (CDS) market to hedge their risk. Whoever got the low tranche, hedge funds typically, used CDS to hedge their positions. And investment banks were on both sides of these markets. They were making markets in CDS, so they were the derivative dealers. At the bottom of the pile, holding everything up, the capital in 
the entire system was not the capital of investors, it was not pension funds, it was not hedge funds, it was AIG - an insurance company (shown in the upper right of the figure).

Investment banks like Goldman and Société Générale were on the other side of that bet. They hedged their risk exposures fully, and even went beyond hedging to short the market a bit. They were on both sides of the CDS market - a vital function in a market-based credit system. The Fed in supporting these markets is doing the right thing in some sense, but it is deeply implicated in capital markets, and we do not know how to think about that. It seems its hands are dirty.

This is the immature risk transfer system, which is getting cleaned up even as we speak. So here is my bottom line, two things that the shadow banking system shows us. The role of a modern central bank is still a lender of last resort, but in a market-based credit system it must also be a dealer of last resort. That means quoting an outside spread and letting the bids come, and they come onto your balance sheet. Also the Fed was supporting the international dollar funding market.

Figure 2.11 shows the London Interbank Offer Rate or LIBOR (the international money rate) minus the overnight index swap (a sort of Fed funds rate). The two rates should be the same. How can there be different rates for borrowing in the international market? There should be some 


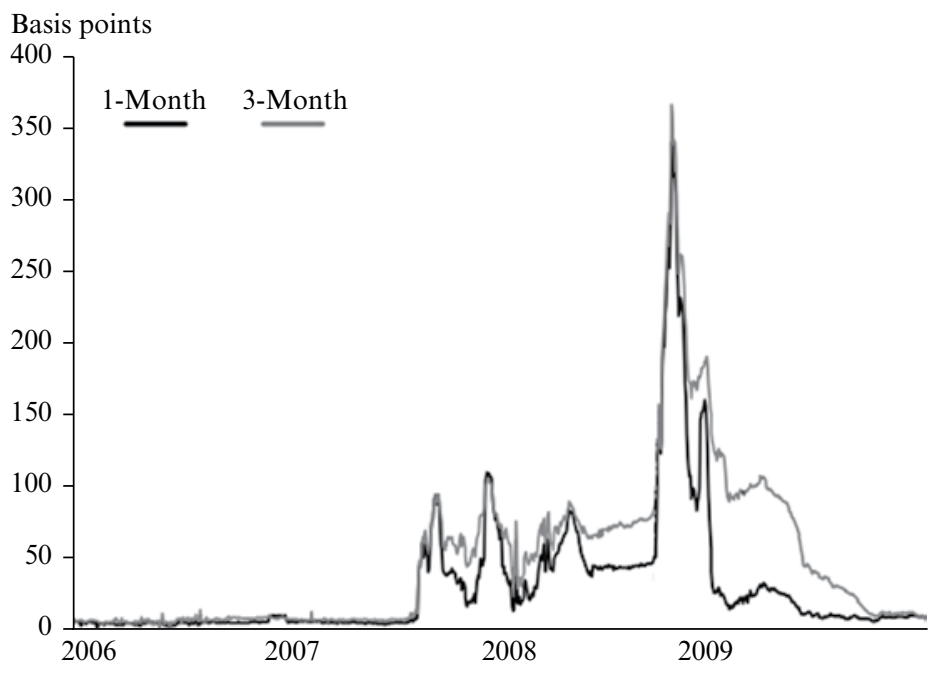

Figure 2.11 LIBOR-OIS spread, 2006-2010

arbitrageur who keeps them close. And so they usually are - except in the crisis.

In the crisis a big gap opened up.

This is an interest rate spread. If I told you this is the spread between the interest rate on the dollar and the interest rate on the peso, it would be easy to interpret. You would conclude that there was a run on the peso or something like that and they had to raise interest rates in order to keep people in the peso instead of running to the dollar. Something exactly like that was happening during the crisis. There is an international dollar system, and there is a domestic dollar system. The Fed used to take responsibility only for the domestic system. It looks like they created a cap, saying we will not let the spread get too big. But 
the point is the Fed was drawn into supporting the international dollar market, whether it wanted to or not. Before the Fed began liquidity swaps it acted to keep the rate gap within bounds - about 70 basis points for the 3 -month series and 40 basis points for the 1-month series. Then in September 2008, everything blew up. The liquidity swaps reached $\$ 600$ billion in the weeks and months following this. The Fed was saying, things are way out of control, we will bring this onto our own balance sheet. They resolved it, and the gap disappeared.

In the crisis the Fed did two things that it was never supposed to do: engage with Wall Street, acting as a dealer of last resort; and become an international lender of last resort for the world. And a good thing, too. It saved our bacon. The consequence is the balance sheet that we have seen and an inability to talk about it. But, we need to talk about it.

What would the world look like if it was all market-based credit? The five important central banks - the $\mathrm{C} 5$, which are much more important than the G7 or G20 - the Fed, the Banks of England, Switzerland, Japan, and the European Central Bank, have a swap agreement among themselves. That is sorting out the crisis in Europe. That is backstopping Europe at the moment - not any agreement between national governments and treasuries, but a gentlemen's agreement between central bankers. They are continuing to try to hold the system together while it matures and grows. 
Maybe they could use some help; maybe they could use some understanding.

\section{Notes}

1. This talk was given at Wake Forest University on March 20, 2012.

2. Stigum has since died, but her co-author Anthony Crescenzi has updated the book.

3. These ideas are developed in my paper 'Three Principles for a Market-Based Credit Regulation', American Economic Review Papers and Proceedings (May 2012).

4. In my class I start with the system as a whole and everyone is confused, but by the last lecture of the class they realize that actually the first lecture of the class was the whole class.

5. The report, a secret memo, was not published until 15 years later.

\section{References}

Mehrling, P. (1997), The Money Interest and the Public Interest: American Monetary Thought, Cambridge: Harvard University Press.

Mehrling, P. (2005), Fischer Black and the Revolutionary Idea of Finance, Hoboken: John Wiley \& Sons.

Mehrling, P. (2011), The New Lombard Street: How the Fed Became the Dealer of Last Resort, Princeton: Princeton University Press.

Stigum, M. (1989), The Money Market, New York: McGraw-Hill. 